\title{
John Griffiths
}

\section{Improvisation and Composition in the Vihuela Songs of Luis Milán and Alonso Mudarra}

The aim of this study is to explore the accompanied solo songs included in two collections of Spanish vihuela music from the first half of the sixteenth century and their possible links with unwritten improvisatory traditions. In contrast to the arrangements of vocal polyphony for voice and vihuela in later books, the songs of Luis Milán and Alonso Mudarra are unique not only in Spanish music, but also in a broader European context. ${ }^{1}$ Until very late in the sixteenth century, most lute songs in European sources are intabulated arrangements of chansons, motets, madrigals, frottole and other polyphonic genres. ${ }^{2}$ The questions raised by the songs considered here concern the provenance of the solo lute song and the manner in which it was cultivated by early practitioners. ${ }^{3}$

Traditional readings of the development of European music see Milán and Mudarra's vihuela songs as something of an anomaly. Older and now generally outmoded theory, rooted firmly in source studies, held that the known tradition of solo instrumental music was born in the late fifteenth and early sixteenth centuries, and that its subsequent development was a process of gradual emancipation from the dominant polyphonic tradition that spawned it. On the other hand, the accompanied solo song has been viewed as one of the great novelties of the late sixteenth century and, as a novelty of its time, is championed as one of the key inventions that separates the musical baroque from the renaissance. These ideas are still purveyed in many general histories of music and under-

1 The only other known song thought to be conceived with an original lute accompaniment is the frottola »Se mai per maraveglia in Franciscus Bossinensis, Tenori e Contrabassi (Fossombrone: Petrucci, 1511), fol. $5^{\mathrm{v}}$. See Véronique Lafargue $\mathrm{K}$, „Par un luth marié aux doulceurs de la voixu: la musique pour voix et instruments à cordes pincées au XVIeme siècle, (diss. Université François Rabelais, Tours, 1999), pp. 147-148.

2 Lafargue, ibid., pp. 40-2, gives just over a dozen sources of lute songs compiled or published before 1550. For useful overviews of the repertories of each of the principal European centres of lute playing, see Douglas A. Smith, A History of the Lute from Antiquity to the Renaissance, Fort Worth, Tex., 2002.

3 Many of the observations of style raised here and some of their possible origins were first raised by John Wand, The „Vihuela de manoe and its Music, 1536-1576 (Ph.D. diss. New York University, 1953). More recently they have been discussed from a different yet complementary standpoint by Lafargue, Par un luth (cf. fn. 1), especially Chapter 5 of her thesis: "Le cas espagnol: sinventions« et compositions sur timbre«, pp. 145-92. 
graduate curricula throughout the world, even if no longer readily accepted by contemporary musicologists, many of whom have long abandoned such linear notions of history. Notwithstanding any reticence to admit unwritten extemporised traditions to the central development of art music, the repute of instrumental improvisers in the evolutionary phase of the instrumental tradition has been amply acknowledged. Although this recognition has restored some of the status these musicians enjoyed in their own time, the lack of tangible evidence of their music and performance practices has all but precluded its assimilation into style-based music histories. A closer understanding of the musical practices of musicians outside the written tradition helps to place instrumental music, and accompanied song, on a broader historical continuum as part of an ongoing process rather than as a novelty of the early sixteenth century. Milán and Mudarra's songs offer some sharp insights into the practices of song performance in the period parallel to and immediately preceding the advent of the written tradition, possibly illuminating some of the extempore musical practices inherited by them from earlier generations of non-musically literate musicians.

The music published by Luis Milán in El Maestro (Valencia, 1536) is in every way mature and accomplished, and evidence of improvisatory practice abounds at every turn in his solo writing and song accompaniments. ${ }^{4}$ Beyond his virtuosic showmanship, Milán displays mastery of his musical medium, achieving eloquence and purpose through intuitive musical skills that are technically crude in comparison to the sophisticated technique of contemporary polyphonists. This so-called crudeness is relative: by comparison to sophisticated vocal counterpoint his voice-leading lacks polish, but the deficiencies are counterbalanced by the sophistication and refinement of his idiomatic vihuela writing. There is no question of the validity of his music, but we have no strong evidence of its stylistic provenance. Milán indicates clearly that his music was generated on the vihuela and then written down, describing his book as »made of many works: which were composed on the vihuela and written down ${ }^{5}{ }^{5}$ The recurrence of many motives, phrases, and passages throughout his works is strong evidence for his music being improvised from a stockpile of idiomatic devices rather than as unique works, each crafted to achieve individuality. John Ward's description of Milán's music as »a bridge between the improvisatory

4 Luis Milán, Libro de Musica de vihuela de mano. Intitulado El Maestro (Valencia, 1536; reprint Geneva, 1975). Modem editions include: Libro de Musica de Vihuela de mano intitulado El Maestro. Publikationen Älterer Musik 2, ed. Leo Schrade (Leipzig, 1927; reprint Hildesheim, 1967); Libro de Musica de vibuela de mano intitulado El Maestro, ed. Ruggero Chiesa (Milan, 1974); El Maestro, ed. Charles Jacobs (Harmony Park, Pa., 1971).

5 Milán, ibid., fol. Aiii: "un libro hecho de muchas obras: que de la vibuela tenia sacadas y escritas«. 
style of the Petrucci and Attaingnant lutenists and the technically more mature style of the Francesco da Miláno generation « locates him historically, and on the questions of style and provenance, Ward identified him with the

Italian improvoisatori whose art lay as much in the manner of performance as in the matter performed. Certainly the impress of improvisation is on many pages of El Maestro. The fact that the music does not lack polish and substance speaks both for Milán's native gifts and for the artistic sophistication of the tradition within which he worked ... [and] ... bespeaks a schooling in an essentially performance art. ${ }^{6}$

In this sense, Ward defines Milán as the endpoint of one tradition as well as the beginning of another, but at the same time notes the exceptionality of his songs, commenting that they "speak the language of the baroque with a renaissance dialect. $\ll^{7}$ Much of my own research on Milán, as well as other studies by Craig Russell and Luis Gasser, has done little more than expand on Ward's observations, illuminating in more detail many aspects of improvisatory style and the parameters within which Milán operated. ${ }^{8}$

Milán's presence at the Valencian court is another significant factor in relation to the questions of the provenance of his improvisatory style. Milan was not a salaried musician, but »a kind of maitre du plaisir «, as Ward described him, at the court of Germaine de Foix and the Duke of Calabria, Ferdinand of Aragon, son of the last Aragonese ruler of Naples. ${ }^{9}$ As can be gleaned from the autobiographical passages of his later book El Cortesano (1561), among other things an account his life at the court in the 1530s, Milán's role included entertaining the ladies of the court, playing games, and singing. ${ }^{10}$ The situations in which Milán describes himself singing always appear to be spontaneous rather than formal. As Gasser has observed, when invited to sing, Milán never had a vihuela with him, an instrument had to be brought so that he could play. ${ }^{11}$

As the court of the former Aragonese rulers of Naples, Neapolitan influence would have been unavoidable and Valencian traditions are likely to have devel-

6 Ward, The vihuela de mano (cf. fn. 3), pp. 247-8.

7 Ibid. p. 161.

8 See John Griffiths, The Vihuela Fantasia: A Comparative Study of Forms and Styles (Ph.D. diss., Monash University Melbourne, 1983); Craig Russell, "The Eight Modes as Tonal Forces in the Music of Luis Milán«, De música hispana et aliis: miscelanea en honor al Prof. Dr. José López-Calo, S.J., en su $65^{\circ}$ cumpleaños, ed. Emilio Casares and Carlos Villanueva (Santiago de Compostela, 1990), pp. 321-62; Luis Gasser, Luis Mildn on Sixteenth-Century Performance Practice (Bloomington, Ind., 1996).

9 Ward, The vihuela de mano (cf. fn. 3), p. 162.

10 Luis Milán, Libro intitulado El Cortesano (Valencia, 1561; reprint Madrid 1874, Colección de Libros Españoles Raros ó Curiosos 7); see also Gasser, Luis Milán (cf. fn. 8), pp. 25-8.

11 Gasser, ibid., p. 33. 
oped through a combination of local and imported influences and the interaction of Spanish and Italian musicians. The Catalan improviser Benedetto Gareth, Il Chariteo, was noted for extemporised singing to the lute in Aragonese Naples, probably following the practice that was common in other Italian regions in the hands of musicians such as Pietrobono and Serafino dall'Aquila, both of whom also served in Naples for a time. ${ }^{12}$ The Neapolitan connection links this study closely to the contribution of Dinko Fabris to this volume, and his exploration of the early villanella as a Neapolitan song sung to the accompaniment of the lute or viola da mano. The common point between our work is the evidence suggesting that both the villanella, the Spanish villancico and several other Iberian song types originated as solo song with lute or vihuela accompaniment. Although the available evidence is circumstantial, it is not improbable, similar to the Neapolitan situation, that many of the songs in polyphonic sources such as the Cancionero de Palacio may have originated as accompanied songs, or were performed as accompanied songs, perhaps to known melodies sung to extemporised accompaniments.

Alonso Mudarra was a very different musician to Milán, probably younger by ten years or so, from a different region of Spain, with a different cultural background, and much more strongly schooled in music of the polyphonic tradition. According to his own testimony in his Tres libros de música (Seville, 1546), he was raised in the cultivated household of the Dukes of the Infantado in Guadalajara, possibly as a page. ${ }^{13}$ His book of vihuela music was published in Seville on the eve of taking up a canonry in that city's cathedral, a position he held until his death in 1580. The Tres libros contains intabulations of music by Josquin and Gombert, and many fantasias that clearly indicate his assimilation of the contemporary imitative polyphonic style. At the same time and like other vihuelists of his time, Mudarra also included music that shows native roots, works such as his variation sets on "Guárdame las vacas" and »Conde Claros « that are at the heart of Spanish popular tradition and the improvised singing of romances. Many of his own songs are likely also to have links to this native tradition. Perhaps through exposure to the professional musicians at the palace of his patrons in Guadalajara, Mudarra had gained first-hand knowledge of the

12 Such singer-lutenists are discussed by Gasser, ibid., pp. 29-33, and a much wider perspective on Italian improvisers is given in Emile Haraszti, "La technique des improvisateurs de langue vulgaire et du latin au Quattrocento«, Revue Belge de Musicologie 9 (1955), pp. 12-31; and F. Alberto Gallo, Music in the Castle: Troubadours, Books, and Orators in Italian Courts of the Thirteenth, Fourteenth and Fifteenth Centuries (Chicago, 1995).

13 Alonso Mudarra, Tres libros de música en cifra para vihuela. Monumentos de la Música Espańola 7, ed. Emilio Pujol (Barcelona, 1949, reprint 1984). 
practices of vihuela improvisation in the traditional style of non-musically literate musicians. His renowned Fantasia que contrabaze la harpa, an elaborate set of folia variations, shows Mudarra to have understood older styles of improvisatory performance practice, probably from the turn of the century. It is likely that the Ludovico whose style the fantasia imitates is the same harpist who came to Spain from Naples in the retinue of the exiled Ferdinand V, perhaps the same Italian from the north who served Ercole II d'Este in Ferrara in the 1470s. ${ }^{14}$ This interpretation of Mudarra's harp fantasia thus suggests that he should be considered from a different perspective to Milán. The purpose of this fantasia was to emulate a past style of a famous musician, and he does this by employing what he understood to be the style of an earlier generation, and the particular individual devices for which Ludovico was famous. The result is a work based on variations on a traditional improvisation scheme, glossed with idiomatic devices that recall Ludovico's playing, and stands in stark contrast to his other predominantly imitative fantasias. Mudarra can thus be seen as a commentator on past tradition, creating works by means of conscious reflective processes outside performance time. In the context of this discussion, he might be characterised as a composer rather than an improviser, in contrast to Milán who was in every way an extemporising singer-songwriter and practising participant in the tradition we are seeking to investigate.

In developing this discussion of Milán and Mudarra, several strands need to be drawn together in order to define the context and the broader significance of the observations made below about individual works. The fundamental themes under discussion here are extemporised musical practice in the early sixteenth century, the relationship between written and unwritten traditions, musical interconnections between Italy and Spain, and the intellectual climate that gave rise to solo song.

Spanish music of the period immediately preceding the books of the vihuelists is best known through several courtly-popular collections of polyphony, most notably the Cancionero de Palacio. The principal genres in these collections, villancicos and romances are the same genres of secular song that predominate in the vihuela books, close to a hundred of the former and two dozen of the latter. Some of these songs may be settings of popular tunes, although romances were also sung to simpler recitation formulae. ${ }^{15}$ It is also likely that

14 On the fantasia see John Griffiths, »La >Fantasía que contrahaze la harpar de Alonso Mudarra; estudio histórico-analíticok, Revista de Musicologta 9 (1986), Pp. 29-40; on the historical context see Egberto Bermúdez, »Sobre la identidad de Ludovico«, Nassarre 10 (1994), pp. 9-16.

15 Ward, The vihuela de mano (cf. fn. 3), pp. 174-5, describes the explanations of the recitation formulae given by Francisco Salinas in De Musica libri septem (Salamanca, 1577). 
many song melodies were newly composed or improvised according to wellestablished stylistic conventions. Some of the songs of other genres in the polyphonic cancioneros that predate the earliest written vihuela music may well have originated as accompanied solo songs, either setting new or traditional melodies, or using well known melodic-harmonic schemes. This is not surprising as many singers and composers of polyphony are likely to have played polyphonic instruments, and there are musical details in these collections that support the assertion. Irregular counterpoint, such as passages of parallel fifths, in early pillancicos may be due to the transfer of instrumental chord positions to a polyphonic setting. While this is speculative and little hard evidence can be invoked in its support, it also coincides with Dinko Fabris' investigation of the early Neapolitan villanella, which suggests a close link with the villancico and performance as solo song with lute accompaniment.

Romance performance was fundamentally a part of oral tradition. The composed romances in the cancioneros are developed from them and some of the best known formulae for singing romances bear names that associate them with particular songs. The schemes of »Conde Claros« and "Guárdame las vacas « (romanesca) were used extensively by instrumentalists as the basis for variation writing, and the improvisation of romance accompaniments on such schemes was evidently the touchstone that led to the development of the variation genre. In addition to these two, the other scheme that proliferates in villancicos and romances of the cancioneros is the early form of the folia, called papana in Spanish instrumental sources until the 1590s. This scheme in particular has been shown to underpin some twenty polyphonic songs in the Cancionero de Palacio and is one of the bases for arguing their connection with popular tradition. ${ }^{16}$ In addition to court performers, the common schemes mentioned were probably also sung widely in urban contexts as well, and the little information that survives on blind, vihuela-playing oracioneros, suggests the existence of urban professional musicians who well may have included such music in their repertories. $^{17}$

The involvement of players of plucked instruments in ensemble performance is another factor that contributes to developing a profile of improvisatory practice. Polyphonic improvisation techniques of ensemble musicians have been

16 Ward, ibid., p. 303.

17 Miguel Angel Pallarés Jiménez, "Aportación documental para la historia de la música en Aragón en el último tercio del siglo XV«, Nassarre 7.1 (1991), pp. 175-212; 7.2 (1991), pp. 171-212; 8.1 (1992), pp. 213-74; 8.2 (1992), pp. 171-244; 9.1 (1993), pp. 227-310. Gasser, Luis Milán (cf. fn. 8), pp. 31-2, also mentions documentation of blind romance singers as late as the nineteenth century. 
outlined by Keith Polk, drawing together diverse documentary evidence from northern Europe, but also noting the extensive interchange between German and Italian musicians. ${ }^{18}$ Lute duos formed an important part of minstrel music making in the fifteenth century, and the duos included in the Spinacino lutebook published by Petrucci are no doubt related to such a performance practice. ${ }^{19}$ Polk draws extensively from Tinctoris to give concrete suggestions on the nature of polyphonic improvisation and, given that Tinctoris spent a good part of his active life in Naples, his explanations of improvisatory techniques may have been in part modelled on his Neapolitan experience.

Traditions of extemporised solo song improvisation most extensively documented in Italy also have relevance to Spanish practice. Recent research has cast significantly new light on the Italian humanistic practices of improvised song using both Latin and the vernacular and practised by both professional minstrels and influential humanists such as Marsilio Ficino. These are perhaps two parallel traditions, although there is insufficient knowledge of the music they sang to judge the extent to which they may be interconnected. On the one hand, Italian court documents indicate improvised singing to the lute practised by lutenist singers with known associations to Naples. It may have been singers like the Catalan Benedetto Gareth who influenced Tinctoris to point to the Catalan practice of reciting epics to the bowed viola, ${ }^{20}$ and it is highly likely that he and other musicians such as the harpist Ludovico transmitted Italian practices to Aragon. The extent that their practices may have influenced singer improvisers including Luis Milán, however, remains a matter for speculation.

Even less tangible are any direct connections between Spanish song and the extemporised singing of Italian humanists. At the heart of humanist song extemporisation was a concern for the restoration of classical poetic metre. Beyond this, we know little of their practice other that they typically accompanied themselves on the lyra, perhaps the lute, lira da braccio, or a generalised allusion to any stringed instrument. Evidence of singing humanistic texts in Spain is scarce although Tess Knighton maintains that it formed part of general education, ${ }^{21}$ and a passage in Luis Vives' Linguae Latinae Exercitatio, a work dedi-

18 Keith Polk, German Instrumental Music of the Late Middle Ages: Players, Patrons, and Performance Practice (Cambridge, 1992).

19 Francesco Spinacino, Intabulatura de Lauto (Venice, 1507).

20 See Anthony Baines, "Fifteenth-century instruments in Tinctoris' De Inventione et Usu Musicae«, Galpin Society Journal 3 (1950), pp. 19-26.

21 Tess Knighton, "La música en la casa y capilla del príncipe Felipe (1543-56): modelos y contextos«, Aspectos de la cultura musical en la Corte de Felipe II. Patrimonio musical espanol 6, ed. Luis Robledo Estaire et al. (Madrid, 2000), p. 64. 
cated to Prince Philip in 1538 , includes a dialogue that provides a classical model for young Spaniards. In this dialogue between the Greek philosophers Pliny and Epictetus, the former exhorts his colleague to »take the vihuela and sing to me while I get into bed and, according to the habit of Pythagoras, I might get to sleep sooner and have sweet dreams. ${ }^{22}$ Knighton has also demonstrated the acquisition of at least one book of polyphonic settings of classical poetry, Paul Hofhaimer and Ludwig Senfl's Harmoniae poeticae (Nürnberg, 1539), for the young Philip II's library. ${ }^{23}$ Along the same lines, the interest in metre that is central to Francisco Salinas' De musica libri septem (1577) shows a concern in Spain for the same issues that lay behind humanist Latin singing. In the broadest sense, their interest was the revival of Orphic song and their desire to emulate the singing of classical antiquity. The books of the vihuelists also abound with classical references, most notably in their titles but also in their prefaces and illustrations. It cannot be mere accident that Milán's book, the earliest source of a collection of solo songs, includes a prominent plate of Orpheus playing the vihuela. ${ }^{24}$ Such references are indicative of a general consciousness of the vihuelists towards the music of antiquity. Milan and Mudarra's songs are part of these widespread cultural and intellectual currents, that despite the lack of intermediary sources, manifested themselves decades later in the lute songs that proliferated throughout Europe, the monodic style customarily attributed to the Florentine Camerata, and the ultimate advent of opera.

The songs of Milán and Mudarra differ substantially although they set many texts of the same poetic genres. Milán included 22 songs in El Maestro, plus ten alternative settings with glossed vihuela parts. He set villancicos, romances and sonnets: four narrative romances, six villancicos with Spanish texts, six in Portuguese, and six Italian sonnets. The melodies of the villancicos are shaped in a way that closely corresponds to the customary musical language of the time and, if not original, may be derived from popular melodies. It is the settings of romances and sonnets that are more revealing regarding improvised singing and appear to show characteristics of extemporised performance. Some of these

22 Knighton, ibid; and Luis Robledo, »La música en el pensamiento humanista espańol«, Revista de Musicologia 21 (1998), p. 406.

23 Knighton, ibid., pp. 64-5.

24 See Isabel Pope, "La Vihuela y su música en el ambiente humanístico«, Nueva Revista de Filologia Hispanica 15 (1961), Pp. 395-402; and Jack Sage, "A New Look at Humanism in 16th-Century Lute and Vihuela Books", Early Music 20 (1992), pp. 633-43. 
songs are built on formulaic patterns while others are constructed from short phrases with internal melodic repetitions that do not correspond with poetic structures. Possibly as a consequence, many of the melodies are bland and unmemorable, with little melodic interest and no discernible attempt to craft lines that have any affective relationship to their texts. This characteristic may well be interpreted as a sign of his greater concern with the manner of performance rather than musical content, a style in which delivery and the performer's art overshadows the musical substance.
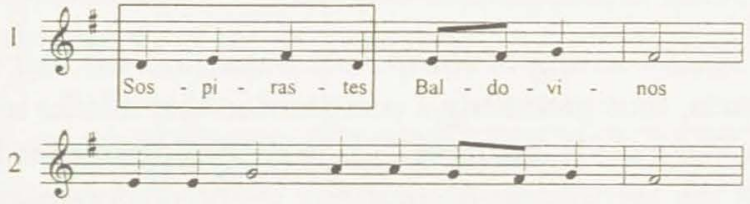

Las co - sas que yo ms que - $r$ - a

3
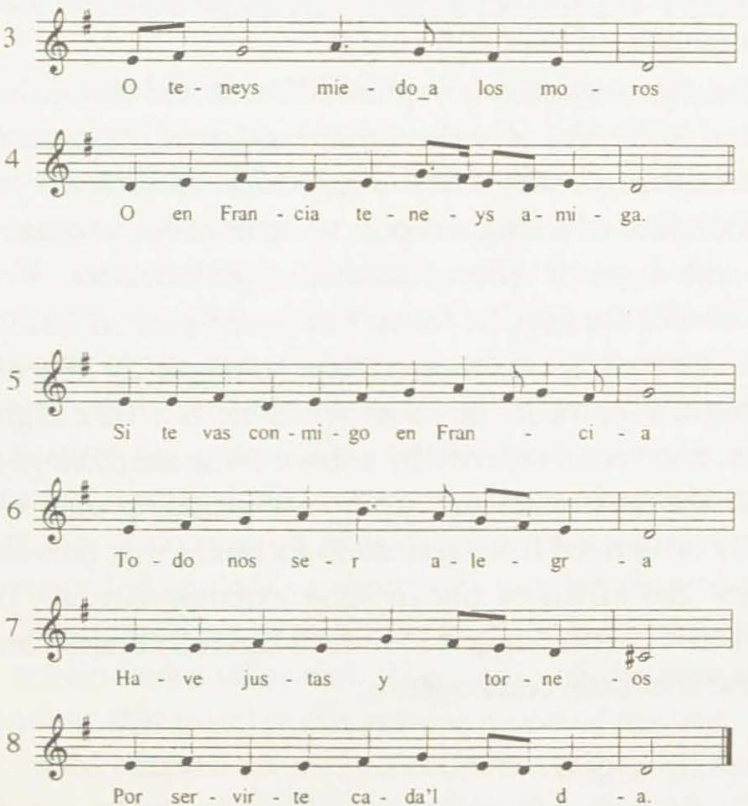

Example 1: Luis Milán, »Sospirastes Baldovinos«, melody

Due to the connections with oral tradition, the romance provides a good place to begin exploring Milán's songs. The romance is a strophic narrative form with 
four-line stanzas that usually repeats the same music for each strophe. Romances are commonly of considerable length and Gasser has calculated that performances of complete texts using the music in El Maestro may have lasted more than an hour. ${ }^{25}$ Milán's romance "Sospiraste Baldovinos « reveals elements that might possibly reflect an improvisatory conception of the music and a possible link with the unknowns of the oral tradition. At the same time the argument cannot easily be corroborated and is presented here with due caution. While there is evidence at our disposal to suggest improvisation in romance performance using formulae for recitation and accompaniment, it supposes an unrealistic leap of faith to argue that the formulae found in this one song are typical of a more generalised practice.

The unusual feature of Milán's setting of "Sospiraste Baldovinos" is that he provides music for two stanzas, thus producing a composition that divides into two separate musical units. The melody (example 1 ) is in mode 8 , transposed a fifth. ${ }^{26}$ The melodic style of the two stanzas is consistent in the predominantly stepwise movement, and the two are linked through the repetition of the initial motive of the song at the beginning of lines 4,5 , and 8 .

Structurally, however, the two melodies are quite different and the melody of the first stanza has several hallmarks of a recitation model: it is formulaic, simple and bland. It would adapt to any text on any topic, and is easy to manipulate during the performance of a long strophic song in order to obtain a broad range of rhetorical and dramatic effect. Successful performance is dependent on delivery. Each verse of the strophe follows the same pattern, rising a fourth, then cadencing by a descending semitone or tone (example 2). The first and fourth verses use the fourth $d-g$, while the inner verses are one tone higher $e-a$. The cadences of the first two verses cadence by a descending semitone $g-f \not$, a third above the final, and the latter two cadence by a descending tone $e-d$. This first strophe could easily be derived from recitation formulae that provided a framework for improvisers like Milán to use in song extemporisation. The melody has no other characteristics that suggest it to be a carefully crafted line; the rising fourth of each verse is of little consequence.

25 Gasser, Luis Milán (cf. fn. 8), pp. 25-8.

26 Milán shows the vocal lines of his songs in the tablature in red ciphers. My transcriptions of Milán's music are made assuming an instrument tuned in A. 


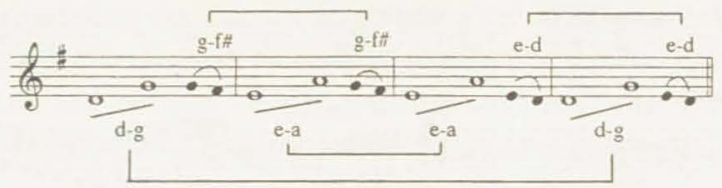

Example 2: Luis Milán, »Sospirastes Baldovinos«, melodic design, strophe 1

The second strophe does not follow a similar pattern, although it is no less simple. Each verse commences on $e$, and moves by ascending motion, and the final cadences are strategically placed on $g, d, c \hbar$, and $d$ to give overall coherence. It could also represent an improvisation scheme, but it is not as overtly formulaic as the melody of the first strophe.

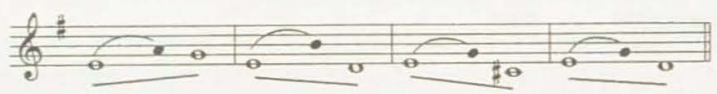

Example 3: Luis Milán, »Sospirastes Baldovinos«, melodic design, strophe 2

It is clear from diverse evidence that singers normally provided their own accompaniments on the lute or vihuela, and this is reinforced by notational format of most lute sources, particularly the Spanish ones that indicate the voice to be sung in red ciphers or apostrophes within the idiomatic tablature notation. In $E l$ Cortesano, Milán is portrayed as a singer-vihuelist in the same way. Accordingly, the accompaniment of »Sospirastes Baldovinos" (example 4) is formulated for the singer-instrumentalist: the accompaniment of the melody line is simple, predominantly chordal and progressively incorporating larger amounts of passing figuration. The redobles between each verse are part of combined vocal-instrumental phrase gestures that only really make sense when the singer is also the accompanist. Milán's music prolonging the final chord of the phrases of verses 1-3 and adds a short coda to mark the end of the strophe.

Setting sonnets to music presents different challenges than strophic romances or refrain-based villancicos. The music of the romance ideally needs to have a character that matches the general mood of the text, yet be malleable enough to be easily adapted to each successive strophe. Villancicos, on the other hand, achieve success more than anything else through a catchy refrain melody, cemented in the listener's memory through repetition. Neither of these techniques is applicable to the sonnet which has no repetition, and is built from concise yet complex textual relationships. Sonnet setting in the sixteenth century was most typically the domain of madrigalists who mostly chose to set these texts 

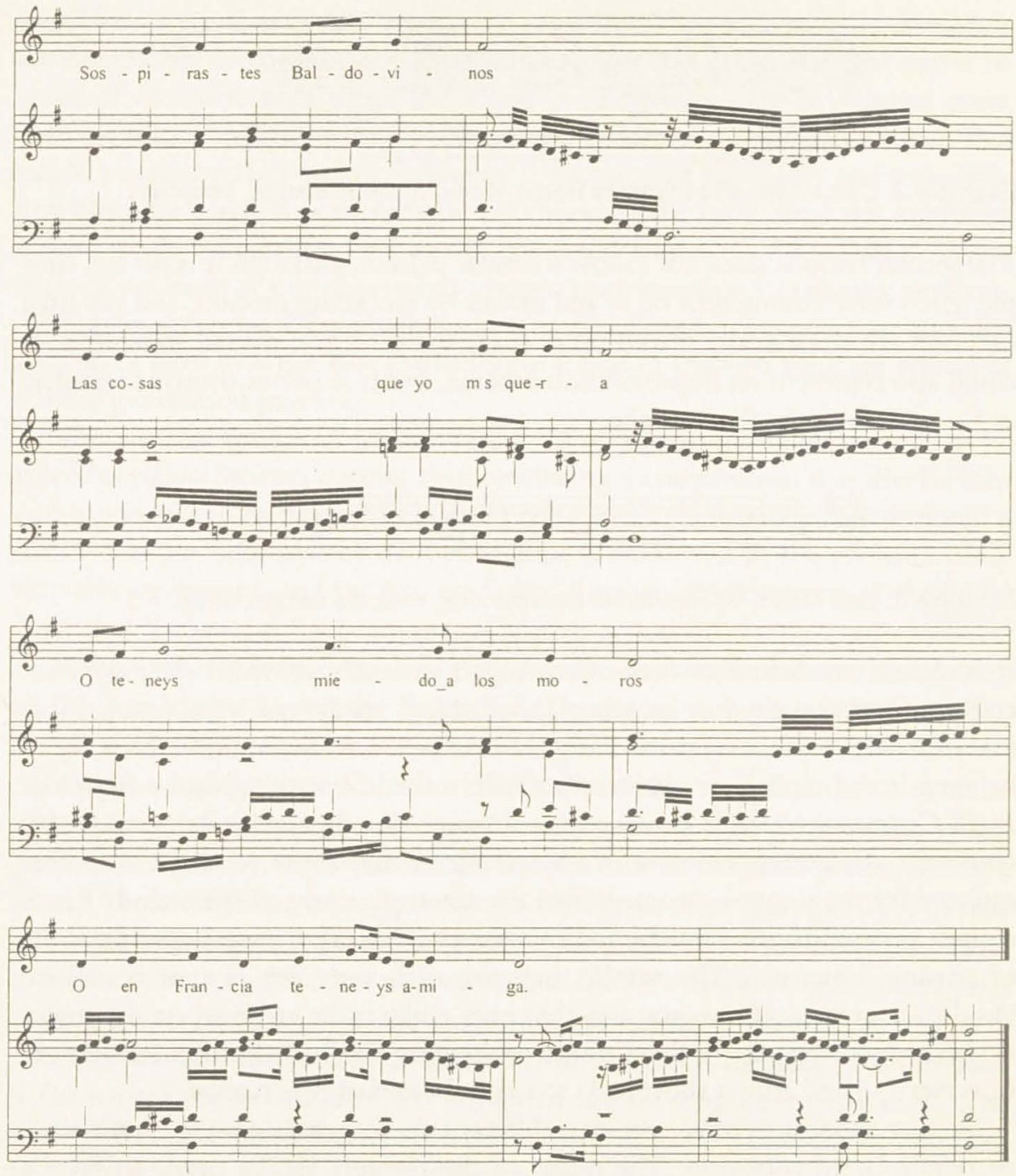

Example 4: Luis Milán, 》Sospirastes Baldovinos«, strophe 1

without repetition of any kind, furnishing each line of poetry with individually crafted music to complement textual meaning. Among vihuelists, Milán and Mudarra are the only ones to have set the sonnet to music, but in notably different ways. Mudarra composed according to the poetic form, usually setting at 
least both quatrains to the same music, and attempting to match music and meaning in a general sense as well as through attention to the detail of specific words. Milán did neither of these things and it is the absence of a meditated concern for both form and meaning that is the strongest evidence to suggest that his sonnets derive from extemporised practice. Ward concluded that Milán was not successful in setting sonnets and describes his setting of Jacopo Sannazzaro's sonnet $\triangleq \mathrm{O}$ gelosia d'amanti« as ambitious, but monotonous and without his more customary finish and charm. Ward also alluded to possible roots in improvisation, "a music of formulas that had been used many times by the vihuelist in singing for friends and at court«. ${ }^{27}$ Milán's version of Sannazzaro's sonnet is doubly interesting because it was also set by Mudarra and comparison of the two versions reveals the differences with great clarity. ${ }^{28}$

Milán's setting of »O gelosia d'amanti«, in common with his other sonnet settings is set to a largely homophonic accompaniment that underpins the melody, reinforces the end of each line through decorated cadential figures, and adds some brief passage work at the end of five verses. ${ }^{29}$ The main structural design of the music can thus be revealed through the examination of the melody alone, and suggests that Milán may well have composed the song extempore or adapted another melody for the purpose, perhaps even during an extemporised performance. An experienced improviser would approach the extemporisation of a sonnet using some predetermined idea at least to initiate the performance, and would either know the text by memory or have a written copy of the poem at hand. To commence an improvisation, it is much easier to think in terms of the melody and accompaniment together, rather than to envisage a melody without a preconception of its harmonisation. If he did in fact extemporise $\mathrm{O}$ gelosia d'amanti «, Milán appears to have used the formula of "Guárdame las vacas« as his point of departure, even if not consciously aware of his choice (example 5).

In elaborating the song further, the initial line is reworked as the second. The first of the two sub-phrases of the first verse, marked (x) in example 6, is a transposition one note lower, but the same cadential turn $(y)$ is retained at the original pitch an harmonised identically. Further motivic resemblances in the entire melody are melodic commonplaces, there is no evidence of the initial material being consciously used to generate new phrases, and there is equally

27 Ward, The vihuela de mano (cf. fn. 3), pp. 289-90.

28 A complete edition of this song is in the Pujol edition (cf. fn. 13), Pp. 116-8.

$291,2,4,7$, and 12. 

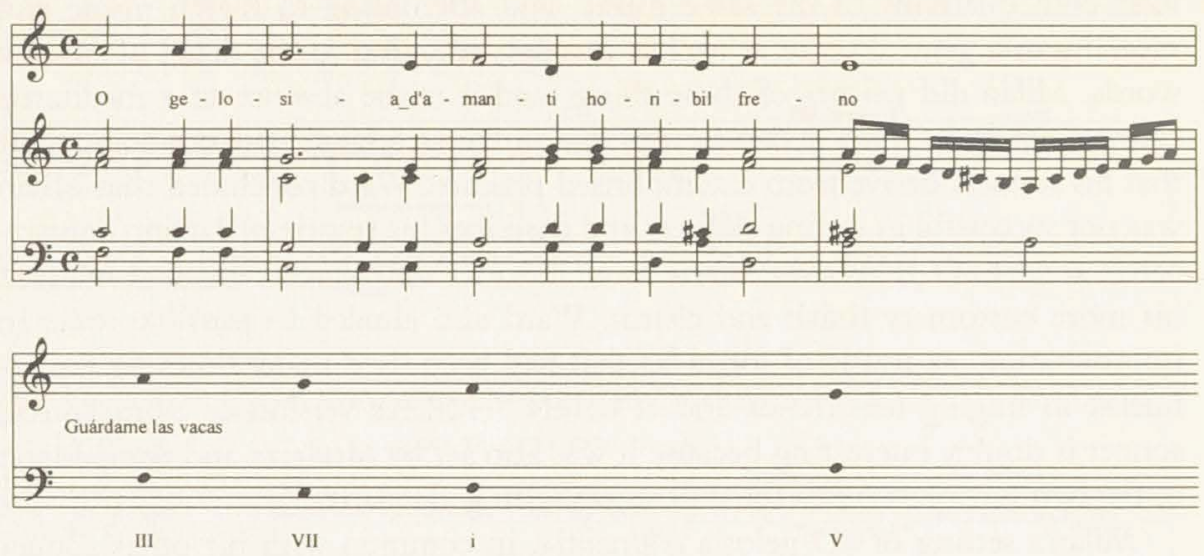

Example 5: Luis Milán, „O gelosia d'amanti«, opening

music

1 O gelosia d'amanti, horribil freno

2 Che in un punto mi volggi e tien si forte;

3 O sorella di le empia et amara morte,

4 Che con tua vista turbi il ciel sereno;

5 O serpente nascosto in dolci seno

6 Che i lieti fior de mie speranze hai morte;

7 Tra prosperi successi, adversa sorte;

8 Tra soavi vivande aspro veneno.

9 Di qual furia infernal nel mondo uscisti,

$10 \mathrm{O}$ crudel mostro, $\mathrm{O}$ pesti dei mortalo,

11 Che hai fatti gli giorni miei si amari e tristi?

$\left.\begin{array}{l}a \\ a \\ b \\ c \\ d \\ e \\ a \\ a^{\prime} \\ b \\ b \\ b " \\ c \\ d \\ f\end{array}\right\}$

little to suggest that Milán concerned himself with crafting a distinctive or memorable melody. The most revealing feature of this melody, however, is a question of repetition; Milán states his melody twice but with no relationship between musical and poetic structure. As can be seen above, the initial melody (phrases a-e) is repeated from verse 7 , the midpoint of the second quatrain, but with the b-phrase thrice repeated, and a substitute line (f) replacing the e-phrase of the first half to bring the song to its conclusion. According to this scheme, there is no formal musico-poetic relationship.

There are two plausible explanations of this repetition scheme. The first is that Milán was adapting an extant melody to a new poem, a melody originally 
I a

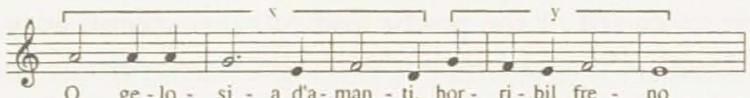

o ge-lo - si - a d'a-man - ti, hor - ri-bil fre - no

$2 \mathrm{a}^{\prime}$

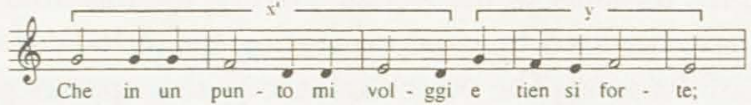

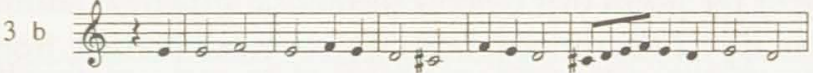
O so-rel- la delem pi-a e a-ma-ra
mor-te,

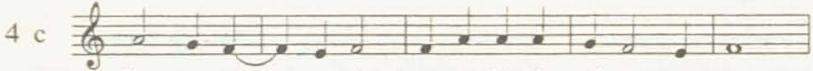
Che con tu - a vi - sta tur-bi il ciel se - re - no;

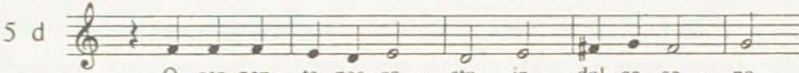
0 ser-pen - te nas-co - sto in dol-ce se - no

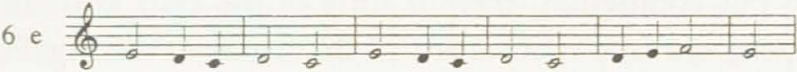
Che i lie- ti fior de mi-e spe-ran - çe haimor -te;

7 a

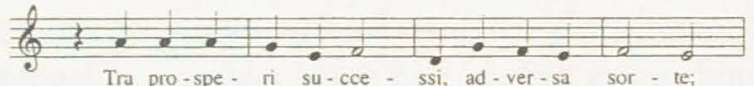

$8 \mathrm{a}^{\prime}$

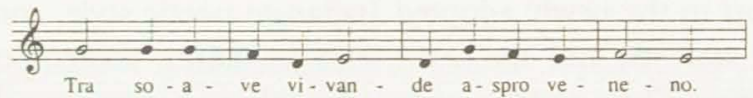

$9 \mathrm{~b}$

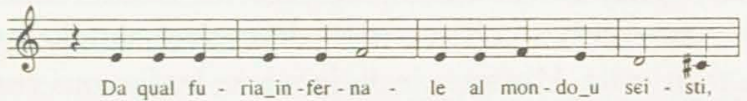

$10 b^{\prime}$

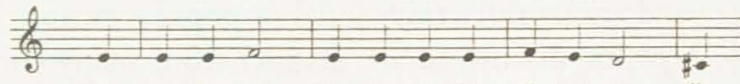

O cru-del mon - stro, o pe-ste di mor-ta - li,

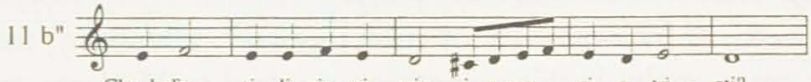

Che_hafat - ti li gior-ni mie - i a-ma ri e tri - sti?

$12 \mathrm{c}$

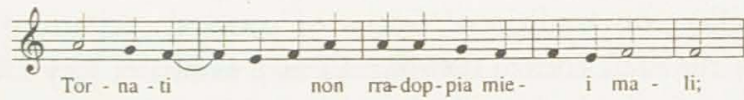

$13 d$

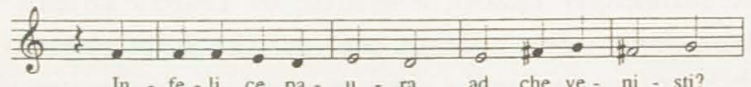

In - fe-li ce pa- u - ra ad che ve - ni - sti?

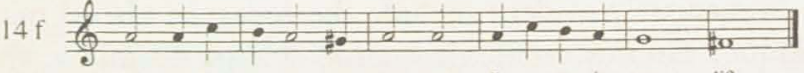

Hor non ba-sta-va a - mor con li suo-i stra - li?

Example 6: Luis Milán, „O gelosia d'amanti«, melody

conceived for a different text genre, and probably with a different number of phrases. In support of this possibility are the several points in the setting where 
the underlay of the text is awkward or the poetic and musical accentuation does not coincide. Secondly, there are few points in the song where melodic gestures impact upon or enhance the meaning of the words. Thirdly, the threefold repetition of phrase b, may have occurred to avoid exhausting the melodic material before reaching the end of the song. The other explanation that appears plausible is based on a reading of the poem that ignores theoretical structural norms. Milán may have chosen to repeat the melody, borrowed or extemporised, from verse 7 because of the pairing of the lines:

Tra prosperi successi, adversa sorte; Tra soavi vivande aspro veneno.
From happy events, adverse fate, From delicate food, bitter poison.

This is the principal point in the poem where melodic repetition coincides with the rhetorical device in the text, and works quite well with the paired melodic phrases a-a'. Apart from this connection, there is little of the craft associated with sonnet setting characterised by its treatment in the hands of madrigalists and points to improvisation as the most likely compositional procedure.

A broader variety of song genres is represented in Alonso Mudarra's Tres libros. His fourteen Spanish songs include traditional romances, villancicos and several settings of sonnets in the newly adopted Italianate poetic style, complemented by four Italian sonnets, and six Latin texts including contemporary, biblical and classical poetry. They reveal a composer able to create remarkably varied songs that unfailingly combine charm with disarming simplicity, and show great sensitivity to their texts. His texts include works by famous contemporary and classical authors and anonymous traditional or popular verses.

The two songs chosen here for discussion are distinct from many contemporary songs notably for their more declamatory style. As this style is once again different from the habitual melodic style of contemporary polyphony, the questions of provenance again apply: is this something original to Mudarra, or could it in some way reflect on traditional forms of musical recitation? The songs to be discussed are the well known romance "Triste estaba el Rey David « and the less known but stunningly beautiful setting of Dido's lament from Virgil's Aeneid, "Dulces exuviae«. These songs are not the only ones in Mudarra's collection that exhibit these particular characteristics; other songs where the same techniques are immediately evident include the romance »Israel mira tus montes", Jorge Manrique's famous verses »Recuerde el alma dormida", the sonnets »¿Qué llantos son aquestos? « and "Si amar por el hombre«, and his settings of "Nisi Dominus» (Psalm 126) and "Exsurge quare (Ps 43: 23-4) which are exceptionally formulaic although not set to the conventional psalmodic recitation formulae. 

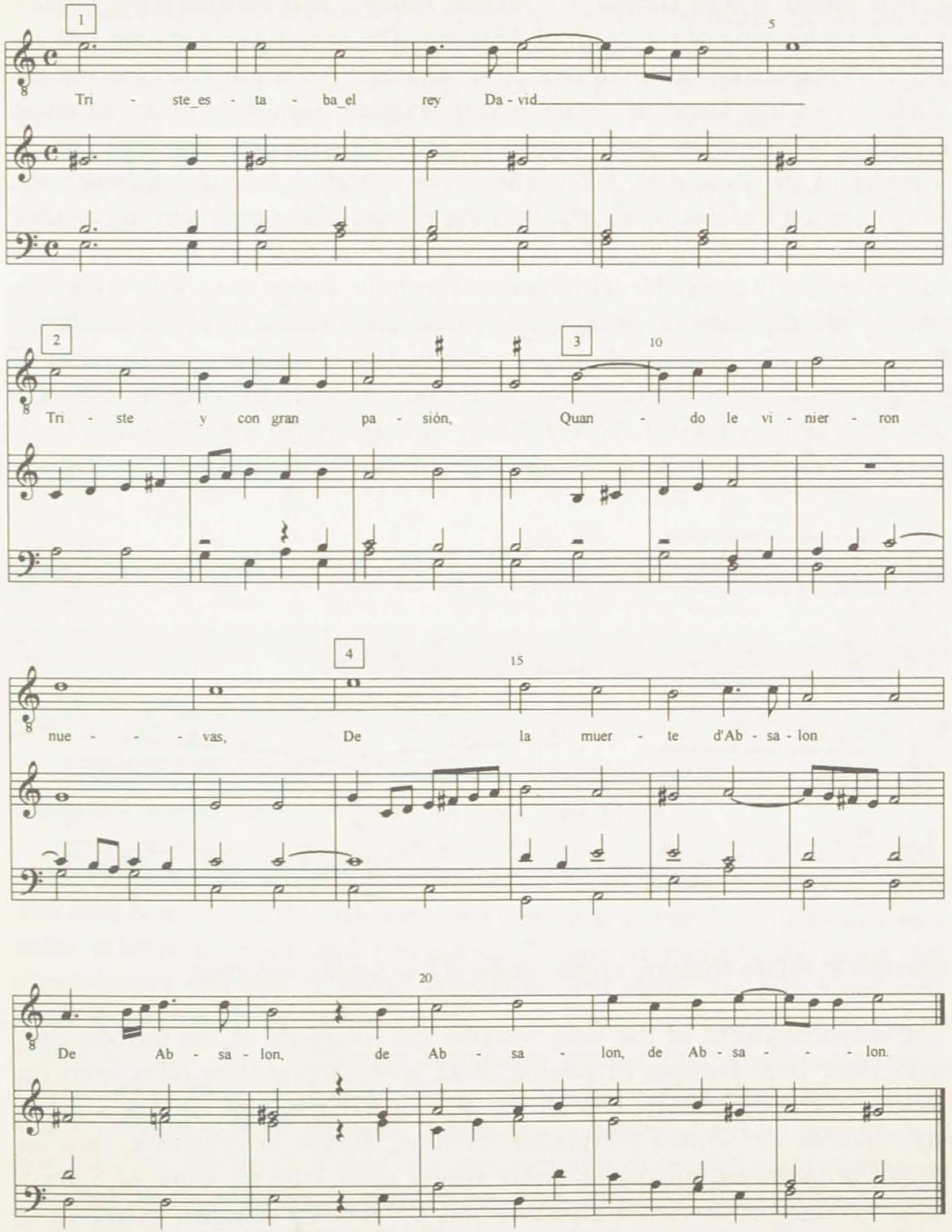

Example 7: Alonso Mudarra, »Triste estaba el Rey David» 
"Triste estaba el Rey David« is a Biblical romance that laments King David's sorrow on learning of the death of Absalom. The opening of the song (see example 7), especially, is reminiscent of ecclesiastical recitation formulae and the kinds of singing found in contemporary popular Spanish laments, although historical origins of the latter cannot be assumed with any certainty. The remainder of the song does not continue the recitation formula, although the song's closing cadence recalls the opening phrase. The simple melodic outline throughout the song, given schematically in example 8 , shows an archaic structure more easily associable with medieval melodic design than with sixteenthcentury norms, based on phrases that ascend and descend between clearly defined points. The opening phrase on $e$ clearly defines the Phrygian character of the piece, and the development of the melody responds to mode 4 , using the lower modal tetrachord almost exclusively throughout the song. The use of $c, \mathfrak{g}$, and $a$ as melodic resting points is also characteristic of this mode.

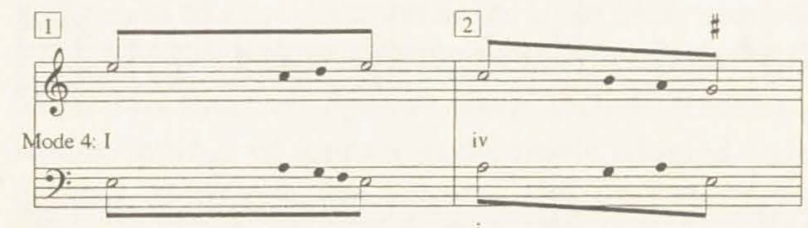

A minor: $V$

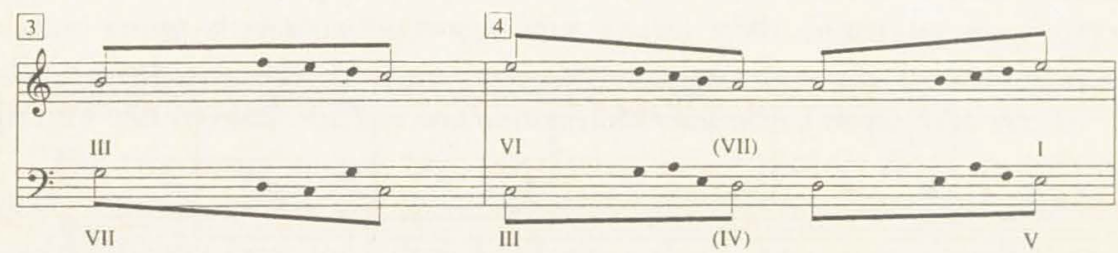

Example 8: Alonso Mudarra, "Triste estaba el Rey David», reduction

The accompaniment of the song matches the simplicity of the melodic line, with some brief passages of passing notes giving momentary relief from the otherwise chordal texture. If Mudarra were in fact trying to emulate a native style outside the written polyphonic tradition, archaic or otherwise, then his choice of harmonic language matches closely what little we know of Spanish style through the cancionero repertory and the romance formulae preserved in instrumental variations. This is seen most effectively if we consider the piece not to be in mode 4, but in a less orthodox manner, as a form of A-minor, concluding on the dominant chord. In mode 4, the principal harmonies that open and close each of the four phrases of the music would be I, iv, III, and VI, but read 
in A-minor, these same chords are V, i, VII, and III, the harmonic vocabulary of both "Guárdame las vacas", the pavana-folia and many other pieces. In fact, the sequence formed by the opening chord of each of the four phrases of the music ( $\mathrm{E}, \mathrm{A}$ minor, $\mathrm{G}$ and $\mathrm{C}$ ) is identical with the $\mathrm{V}-\mathrm{i}-\mathrm{VII}-\mathrm{III}$ opening of the pavana-folia, the same formula on which Mudarra based his deliberately retrospective Fantasia que contrabaze la harpa. The harmonic and melodic structure of the piece is given in the analytical reduction of the song.
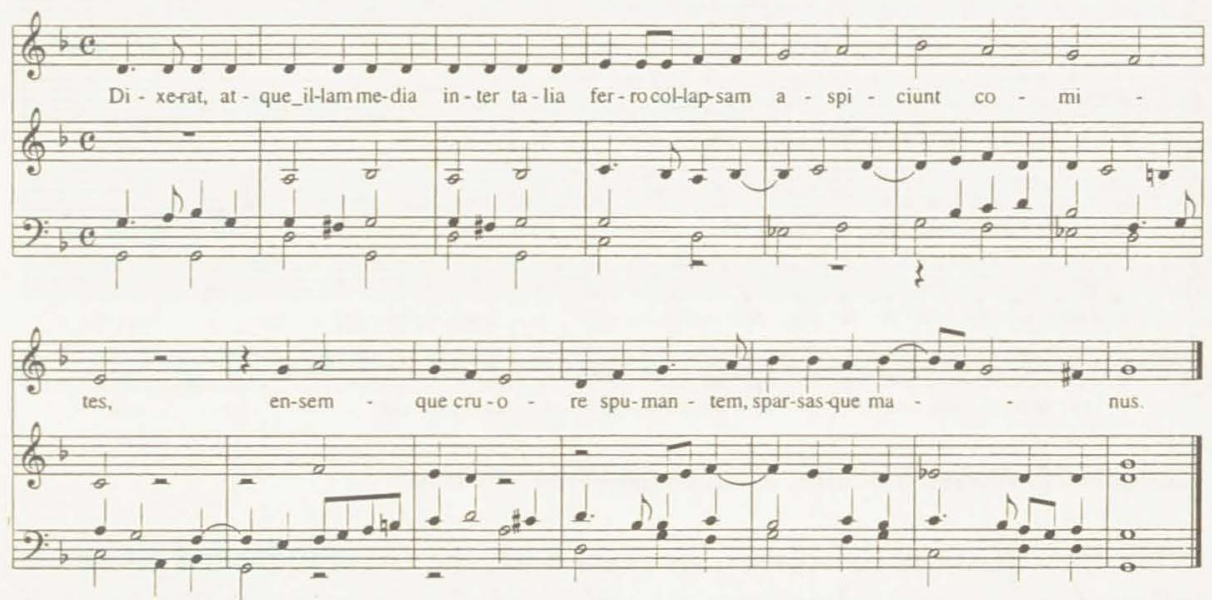

Example 9: Alonso Mudarra, »Dulces exuviae«, bars 33-46

Mudarra's inclusion of settings of poetry by Virgil, Horace, and Ovid in his Tres libros is unique in the early lute song repertory, but probably indicative of a wider practice in Spain and throughout Europe. It immediately recalls the improvisatory practices of Italian humanists cited earlier and which we now know also to have been practised in Spain in some form. It was from the 1539 Hofhaimer and Senfl anthology Harmoniae poeticae that Mudarra arranged Hofhaimer's setting of Horace's Beatus Ille for his vihuela book. Perhaps the simple metrical style of Horace's bucolic poem was emulated by Spanish improvisers, but Mudarra's setting of "Dulces exuviae" exemplifies a declamatory style that has no equal in the early repertory of songs accompanied by the lute or vihuela and whose origins and traditions remain an enigma. The main feature of the melodic style - it can perhaps be styled a monodic recitation - are the declamatory passages of repeated notes, generally accompanied by static harmony. The most striking of these passages occurs at the beginning of the 
final strophe of the piece (example 9), but others occur in bars 6-8, 19-23, and 27-29.

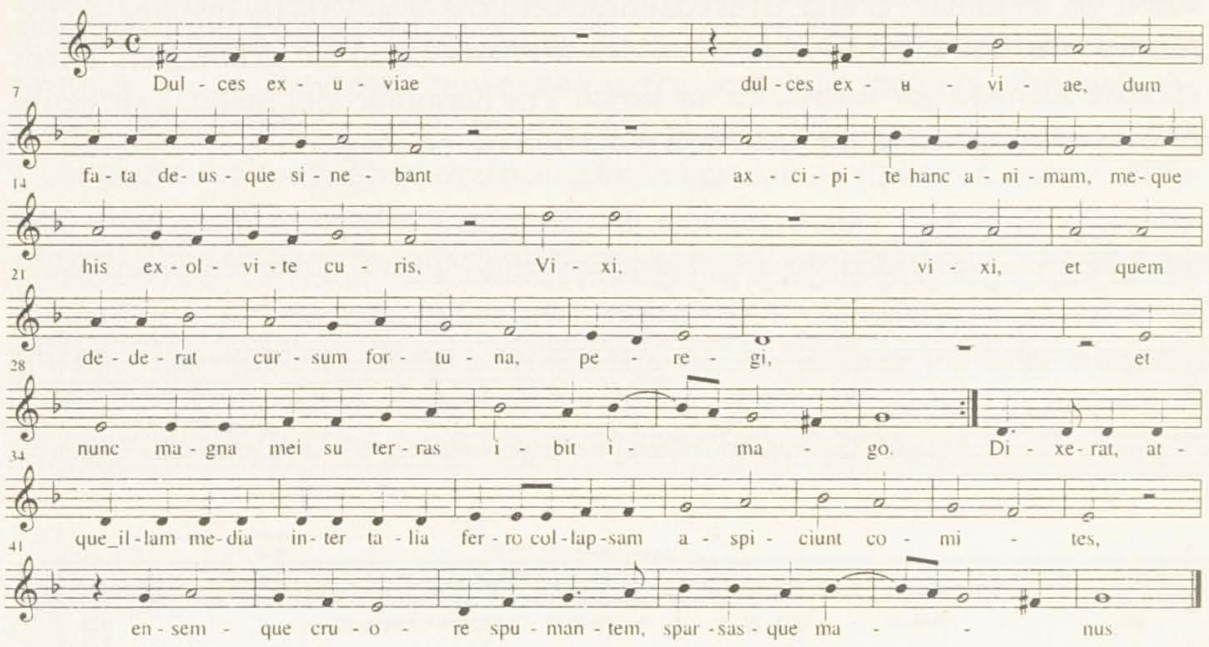

Example 10: Alonso Mudarra, "Dulces exuviae», melody

While these passages in isolation are quite brief, the use of reiterated pitches or inflected reciting tones dominates the entire melody (example 10). The first half of the piece (to bar 23) is largely built from phrases that oscillate around $a$ and $g$, descending to $f$ at phrase ends much the same as psalms in the sixth mode. Other characteristics of the declamatory style are the substantial rests between phrases that are filled in the accompaniment by cadential formulae, the unpredicted and dramatic leap to $d$ in bar 17 , and the low $d$ reciting tone from bar 33. Using a formula similar to his sonnet settings, the text is set with the first musical section (bars 1-32) repeated three times for three quatrains of poetry, followed by the dramatic concluding tercet. Overall, the music gives the impression of trying to emulate speech in song and enhancing the drama of the text in the process. It appears to embody the same principles as the late sixteenth-century Italian monodic style and, however tentative the findings might be, this and the other songs discussed here seem to point away from a style founded in the polyphonic tradition. At this stage it is impossible to draw conclusions as to whether these stylistic features may be directly attributable to all or any of the musical practices that have been mentioned in the foregoing discussion, and which remain largely a matter of speculation. Although this study reveals some of the features of the original songs of Milán and Mudarra that 
distinguish them from other known early sixteenth-century songwriting styles, there are still many unknown factors that impede a deeper understanding of their provenance whether it be popular song, recitation practices, the improvisation techniques of minstrels or humanist singers, or just these vihuelists' own conception of how the singers of antiquity performed. 